\title{
The Role of the University of Jordan in Promoting the Principles of Good Citizenship for its Students and How to Implement them
}

\author{
Maisoun AL Dawairi ${ }^{1}$ \\ ${ }^{1}$ Educational Sciences Faculty, The University of Jordan, Amman, Jordan \\ Correspondence: Maisoun AL Dawairi, Educational Sciences Faculty, The University of Jordan, Amman, Jordan. \\ E-mail: hu_ss_am@yahoo.com
}

Received: September 9, 2018

Accepted: October 1, $2018 \quad$ Online Published: October 15, 2018

doi:10.5539/mas.v13n2p177

URL: https://doi.org/10.5539/mas.v13n2p177

\begin{abstract}
The citizenship is the fact that a person, for a family or a group, to be officially recognized as a citizen, that is to say a member of a city with the status of city , or more generally of a State. There is no citizenship in general, even though many personalities have claimed to be world citizens or cosmopolitan. This study aims to investigate the role of the University of Jordan in promoting the principles of good citizenship for its students and how to implement them. A well-designed online questionnaire developed and used to collect primary data and the statistical analysis has been applied to get the results. The results revealed that the sample students' agree that the University of Jordan has high percent in promoting the principles of good citizenship for its students for all of political, social and economical values.
\end{abstract}

Keywords: citizenship, student, education, rights, city, equality

\section{Introduction}

Citizenship is defined as the status of the citizen who belongs to the homeland and his or her affiliation entails obligations such as loyalty, defense and performance of labor, and entitles him to rights such as the right to education, care and work. Accordingly, citizenship is a strict relationship with a constitution and laws that binds the individual and his state, Between citizens, coexistence, and the democratic system. Often the most straightforward questions reflect both the the most complex questions, the lessons of the most striking news and the problems the most fundamental. How to develop citizenship? is one of them. She returns implicitly to the coherence of a solution, such as these practical manuals entitled to work efficiently? Or "how to cure her plants?" But precisely, it is not certainty that citizenship can be approached this way, despite its apparent homogeneity and unanimity that seems to surround its social and political value.

So, it is necessary more than ever to question ... the question to better put into perspective the issues it covers and to better appreciate the relative kept on citizenship. "Developing citizenship" assumes first that the latter a circumscribed, stable and known object that can be extended beyond its limits initials, in short that there is room for growth towards a "plus" of citizenship. "How" then supposes that there are ways of doing things that is to say action plans predictable, thereby producing the requested effect. But on these two axes in the main, a historical and political examination of the notion shows all the uncertainties assail both the citizen and the educator.

This does not mean that the question is irrelevant. On the contrary, it clearly corresponds to a profound questioning of Western societies and perhaps especially from French society, because of the special relationship that this one maintains with a notion that structure since the 1880s: secularism. He became quite common, indeed, to evoke the "crisis of citizenship". The indicators would be many in various fields: disaffection of individuals for the militant commitment, whether political, trade union, national or local; disastrous picture of politiciansin the public opinion; rate of abstention growing at all votes;ignorance by the younger generations of the rules of life in society and its translationcontrary to either usage, law, etc.

But the feeling of unease and disorder created by these difficulties of social functioning, no doubt proved, is neither sufficient to define the notion of citizenship nor to ensure that its good health or development would be such as to remedy it. The the question of the development of citizenship, when put by educators, translates concern about the evolution of social functioning and seeks to draw on the sources of republican culture, responses as effective as those that led to the establishment of the secular school, compulsory and free in France of the Third Republic. 
However, he is little likely a century later, in the context of the weakening of the nation-state 1 , a such a perspective is conceivable. In other words, it is no longer possible to think of the citizenship, which is above all the central question of the formal relationship of the individual to the in a society and a world in which multicultural and multiethnic populations, where the centralization of political regimes and public institutions, and where the chosen economic system prefers adaptation to market fluctuations to the stability of the collective decision.

In addition to legal status and social roles, citizenship is also defined by values. We can evoke at least three, which are traditionally attached to him:

- The civility: it is an attitude of respect, both with regard to other citizens (eg polite), but also to the various buildings and places of public space (eg public transport). It is a mutual and tolerant recognition of individuals among themselves, in the name of respect for the dignity of the human person, which allows greater harmony in society.

- The citizenship: it is, individually, to respect and enforce the laws and rules, but also to be aware of its duties towards society. More generally, civility is linked to an active behavior of the citizen in the daily life and public, which leads him to act so that the general interest trumps the particular interests.

- The solidarity: as long as the citizens in a conventional design, are not mere individuals juxtaposed, but a set of men and women committed to a common project, solidarity is necessary. It corresponds to an attitude of openness to others, illustrating the republican principle of fraternity. In these conditions, solidarity, which consists in helping the poor, directly or through public policies (eg redistributive tax) is very directly related to the notion of citizenship.

\section{Related Work}

Molina Girón, L. A. (2012) attempts to bridge a gap between what continue to be two separate fields: citizenship education and multicultural education. The research attempts to break new ground in two ways. First, it reveals how citizenship education instruction is practiced within regular high schools serving culturally diverse communities, and whether it responds to the social differences found in the classroom. Secondly, it examines how multiculturalism as a component of course content is addressed within citizenship education . Citizenship education research and theory identifies school-based citizenship education as a promising approach to educating a civically-minded citizenry (Carnegie Corporation of New York \& CIRCLE, 2003; Crick \& Porter, 1978; Newmann, 1975; Parker, 2003)

Harkavy (2006) When colleges and universities give very high priority to actively solving strategic, real world, problems in their local community, a much greater likelihood exists that they will significantly advance citizenship, social justice and the public good. More specifically, by focusing on solving universal problems that Harkavy: role of universities in advancing citizenship are manifested in their local communities, institutions of higher learning will be better able to realize Bacon's brilliant proposal that universities should closely collaborate across cultures and national boundaries to advance human welfare. Even more specifically, that strategy will enable them to translate the theoretical advantages of the One University idea into practical action and help create the universityassisted community schools which, this article concludes, is one of the best ways to help develop democratic students, K-16, and thereby significantly contribute to the development of democratic schools, democratic universities, and democratic Good Societies in the 21st century.

(Ke, L., \& Starkey, H. 2014) they argue that the social network sites contribute to youth informal civic participation. However, these sites do not directly lead to an ideal public sphere which promotes citizenship literacy. Indeed, ironically the internet may promote participation, but undermine the civic in the sense that the internet also encourages individualization, or at least a fragmentation of social and political debate (Bennett et al., 2006). Active civic participation is more than simply acquiring information (Livingstone et al., 2005). In other words, although the internet and SNSs have the capacity to be a significant vehicle for changing Chinese democratic citizenship, the extent of change depends on how young people actually engage in real civic actions. We conclude that there is significant potential for citizenship education in universities. Students could benefit from opportunities to consider the implications of digital citizenship learning, as well as from practical opportunities to reflectively engage in civic participation (Bennett et al., 2009). A formal or informal learning programme might cover knowledge about democratic citizenship, digital media, and the public sphere. It could include skills of expression, communication, negotiation, compromise, cooperation, and activity organization, as well as promoting democratic civic values .

Matsuda, N. (2014) This article focuses on citizenship education supplied by universities as a way to help promote citizen participation. Employing an economic approach ton university behavior in a competitive market, theoretical insight is offered into whether universities can supply citizenship education. The findings reveal, on the one hand, 
that universities have an incentive to educate "good citizens" and that subsidies, including governmental financial support, contribute both to an increase in the number of students and to an improvement in citizenship education programs. It is demonstrated, on the other hand, that universities are unenthusiastic about supplying education for "adequate citizens." Universities emphasize commercial revenue rather than citizen development, and although governmental financial support might allow more individuals to receive an education, this is unlikely to be spent almost exclusively on citizenship education programs .

Kymlicka, W. (1997) Although it is widely accepted that a basic task of schooling is to prepare each new generation for their responsibilities as citizens, the appropriate form and content of citizenship education is often controversial. This paper discusses some of these controversies. I begin by arguing that citizenship is more complicated than is often realized, and that even 'minimal' conceptions of citizenship impose significant obligations and constraints on individual and group behaviour. I then consider three inter-related areas of debate: whether citizenship education requires common schooling; whether promoting responsible citizenship requires promoting personal autonomy; and whether promoting a shared civic identity requires teaching not only shared political values or principles but also promoting particular national or cultural identities. These three issues help illustrate the centrality of education for citizenship to both political theory and educational philosophy .

Farouk and Husin (2011, p. 154) state that it is important that students 'internalise that democracy is not a spectator's sport and consequently value active citizenship as an indispensable element in public life'. This statement makes particular mention in the chapter and congruent with the author's belief of how citizenship education and notions involving values should be taught. It advocates active participation, and experienceoriented teaching-learning methods for citizenship education and civic responsibility, than passive teaching-learning processes. As various fundamental principles of democratic life are being threatened both on a national and international scale, education is increasingly being expected to provide the response and possible answers. Teachers and teacher education then become crucial elements to citizenship education, which may include the focus of teacher education courses and perhaps vitally, the characteristics of teachers themselves. This paper incorporates (Xiao \& Tong's, 2010, p. 45) definition of citizenship education as 'any educational experience that promotes the growth of individuals in regard to their civic capacities'. This study aims to investigate why student teachers think citizenship education is important, how it needs to be implemented, and what contents they perceive to be core to citizenship education.

(Monicah, Z. 2018) presented a synopsis of the research process and the research findings on the democratic citizenship education in Zimbabwe's institutions of higher learning and its implications on teaching and learning.

\subsection{Citizenship, Object or Principle?}

There are three main ways for philosophical discourse to consider the question of the citizen. A normative approach: what the citizen should be, subjective level, political and activist. A transcendental approach, which consists in trying to think about the conditions of possibility of any human society (Hobbes, Locke, Rousseau and the antinomy identity / alterity). A phenomenological approach: citizenship is a phenomenon legal and social, an effective institution (Aristotle). It is in this last approach that he seems to be the most relevant to situate oneself if one wants to have the most means to understand the question and answer them.

It is therefore necessary to focus on the concept of citizenship in itself, to approach it without prejudice with the hindsight that historical and sociological observation allows, accepting that it be dressed with variable connotations by the context of time and place. It is therefore possible to identify the two foundations that characterize it universally from the city Greek until today: the political fence; the enjoyment of the law.

\subsection{The Political Fence}

When a political community uses the notion of citizenship, it is to assign it the fundamental function of inclusion / exclusion. It is indeed in the proper sense of a distinction, separation, discrimination. Citizenship refers to individuals as members or non-members of the political community (foreigners or barbarians). Its valuation is to strengthen the identification of members in their communities and to confirm the legitimacy of the power that defines it. The constraining and conservative nature of the Therefore, citizenship should not be underestimated because it is the very reason for its existence.

\subsection{The Enjoyment of the Law}

Citizenship is also a status, a potentiality, a faculty: that of obtaining society as a whole the benefit of certain acts or behaviors. The individual did more to beg in the private sphere or in sub-state communities the protection of its most fundamental interests, as these constitute real rights and holds the law, identical for all. In this respect, citizenship is inseparable from legality, the rule of law, public freedoms and fundamental rights and the principle 
of equality which crosses. In this dimension appears the contingent nature of citizenship, subject to human laws, thus accessible to the evolutions that the legislator imprints on it, and legitimizing the action of a State from which it cannot emancipate itself.

Thus analyzed, citizenship is not frozen in its dual function fundamental. It is also invested over time by the representations of the actors political and social, giving rise to two ways of considering it. On the one hand, citizenship is a legal reality, grouping categories, regimes and subjects of right, which can be fully described by standards and amenable to treatment litigation. We will refrain here to detail them to refer to the regime of nationality, election and public freedoms. But on the other hand, it is also an ideal carried by the actors themselves, a way of thinking and valuing belonging to their political community. This aspect, which receives more attention in the context of a project, is manifested by four components that can be invested with more or less intensity but none of which is self-sufficient. Citizenship manifests national identity; she confers legal status on the individual vis-à-vis the political community; she attributes social roles relating to participation in the life of the city; finally, is valued as a set of moral qualities.

\subsection{Citizenship Set of Rights and Obligations}

The development of modern citizenship results, according to the English sociologist T. H.Marshall, of three major stages. First, the affirmation of civil rights in constructionof the liberal state in the 18th century: it is more or less in France of human rightsproclaimed by the Revolution. Then, the conquest, in the 19th century, of the political rightsnecessary to institutionalize parliamentary democracy: universal suffrage marksthen the suppression of the distinction between passive and active citizens. Finally, the $20^{\text {th }}$ century is that of the establishment of social rights: it is the recognition of the right to healtheducation, economic and social welfare entrusted to the welfare state. It is thereforeattempting to break down citizenship from a legal point of view into threecivilians who protect the individual against the state; political rights allowing the citizen toparticipate in public management and the production of law; social rights which establishthe individual's claims on the company which is obliged to provide him with certain benefits orcompensation. In reality, this scheme is not really historic, because the three steps and thethree components were acquired in principle in France since the Revolution, and inGermany the welfare state preceded universal suffrage, but it is at least explanatorycontent of citizenship.

\subsection{Citizenship, Active Participation in the Life of the City}

Until the middle of the 17th century, citizenship is confined to the enjoyment of the law without any connection with popular sovereignty. For Hobbes, who wrote "Le citoyen" in the subtitle,"Or the foundations of politics", the term citizen is synonymous with that ofsubject and citizenship of Athens is an extraordinary exception. From the end of the 18th centuryon the contrary, it is unthinkable to separate the notion of citizenship from that of participation. The latter is conceived as absolutely indissociable, because the individual must contribute to theformation of the law to submit to it being assured that it does not threaten its rights natural. Citizenship as we know it since the democratic revolutions is itself only if it includes both dimensions:individual natural rights and participation in the production of law. On the other hand thisanalysis makes it possible to distinguish, in the theories of citizenship, those which consider the civic participation as a public value in itself (Rousseau,Mill) or as a simple instrument of protection of private liberties (Constant, Bentham). She also explains the fluctuation of companies by changes in the balance between these two components. Too much civic participation leads citizens to challenge the power monopoly of leaders; too much withdrawal on his individual rights deprives legitimacy of the mandate of the leaders. The disaffection of civic involvement and participation today denounced comes from fact that the development of state interventions in the areas of everyday life promotes a certain passivity of citizens. But the new phenomenon is that the thing public perception is now perceived as an impediment to market mechanisms whose individuals feel they derive greater profit, at the risk of forgetting, on the one hand, that it is the State guarantees the security of trade and the compensation of socio-economic inequalities deemed acceptable, on the other hand that the enjoyment of the law also presupposes respect for of their obligations.

\subsection{Citizenship Set of Moral Requirements}

Beyond the social roles defined by the legal status of the citizen, the outline of the "good citizen", that is to say a set of attitudes and behaviors that translate a desire and a pleasure to fulfill one's civic duties. On the side of civil servants and elected representatives, its name is "sense of public service" (or of the general interest); on the side of their constituents, it is called "civism". Citizenship is therefore supported by a number of moral norms aimed at the acceptance and internalization of collective duties vis-à-vis of the society. It is therefore both a virtue and a technology of conformity or even of social abnegation. The three revolutionary components of civility translate it fairly the duty to vote, the military duty, the fiscal duty, which must not be at the scope of doubts or negotiations on pain of losing their raison d'être and their role as pillars of democracy. The Third Republic tried to attach to 
them the duty to educate them and the duty of solidarity, which can, however, be said to have not acquired the same strength than the previous three.

This last way of approaching citizenship makes it particularly possible to take stock on two essential elements. The first is the permanent but not unambiguous link between citizenship and representation. It is based on institutional exclusions within the body of citizens. The latter have always existed: Greek democracy has never been confused with representation. In the ancient city any citizen could take part in vote of the law. But that did not prevent several institutions from limiting the influence of "basic" citizen on the political life: proposal of laws by the public authorities, count voice by orders, etc. Under the Revolution, the Constitution of 1791, a two-round vote allowed to deprive some active citizens of the possibility of being elected. The difference between the ancient and the revolutionary citizenship comes from the mechanism of representation that delegates to elected officials the power to produce the law. This delegation can be interpreted as reducing citizenship to the sole power to give a warrant. But, he is It is therefore possible to emphasize that the purpose of the representation is to operate a social selection with representatives, better than most, of skills to discern the general interest and moral qualities to respect it. The representation of citizenship in terms of qualities, values or moral requirements is not innocuous. The second element is the frequent confusion between citizenship and civility. The citizenship has been defined in its two components as having on the one hand a protector of the individual, on the other hand a participation in the life of the City. The first slope is civil, the second is civic. However, a trend is now asserting that prevails civil citizenship on political citizenship. The first article of the Code of Education French language, for example, proclaims that "the right to education is guaranteed to everyone in order to allow him to develop his personality, raise his level of initial training and continues to integrate into social and professional life, to exercise its citizenship "." The priorities of education are guided by the notion of personal fulfillment, access to knowledge is intended to ensure the child's future integration into a given social system. These objectives evoke an idea of the enjoyment of citizenship without that there is a clear political regime5. Similarly in the field, the goal of civic education exposed in French school curricula primarily considers the civility as a means of "pacification" of schools. But we cannot fail to notice that this trend has already been observed in history, and it is not fortuitous that this is at the moment of the appearance and the theorization of liberalism. The liberal anarchists conceive of society as a natural harmony (the "hand invisible "by Adam Smith). Individual workers see their needs complement each other spontaneously: it is therefore no longer necessary for the individual to give up some of his interests to preserve a hypothetical general interest. Public space and citizenship naturally disappear before the only relational modality, a direct relationship between citizens between them, named ... "civility". Even in the attenuations of liberalism, which recognize the State as having a minimal corrective function, citizenship is only tolerated as an instrument necessary to overcome the defects of society and the condition of the individual in his relation to the other is essentially conceived as civility.

The summit of ambiguity is reached by the denunciation of incivilities, used by the press, but also by the statistics of the Ministry of Justice. By incivility, sociologists and psychologists heard behaviors disrespectful of social conventions or community-specific morality (whereas incivism is the result of contrary behavior). to the definition of the virtuous citizen as defined by law and republican morality).

But what is now denounced as incivilities goes far beyond the question of social and moral conventions: these are simply offenses criminal. It therefore becomes clear that wanting to fight against criminal incivilities with nonlegal educational means is an aberration, and wanting to get young people to the civility without education in citizenship, a chimera.

\section{Research Methodology}

This study analyzes the extent to which students have sufficient awareness of e-learning and its relation to selfstudying and academic achievement. The original sample on which the study tools were applied consisted of 140 students. In this study, the basic elements of the methodology that are discussed. are illustrated the Data Collection and Response rate, Research Population and sampling, Questionnaire design and the statistical techniques used to interpret the data.

\subsection{Research Population and Sampling}

The population in this research were students enrolled in the University of Jordan, the sample of this research consists of students from educational faculty in the university of Jordan. Students are divided into two groups' undergraduate student and graduate students from different majors. Random Sampling has been used to determine the type of sample used. So each element in the population was had equal chance of being selected as a subject. The size of the representative sample has been calculated using quota sampling to be 140 students 


\subsection{Data Collection}

The data collected using online questionnaire built using free Forum tool from Google and the link of the questionnaire was provided for students in the computer laboratory. According to Chisnall 1997, the non-response is a critical limitation of a research, and in order to reduce a non-response rate, the researcher was available at the time of disseminating the questionnaire. questionnaires were distributed on a random sample of graduate and undergraduate students, all questionnaires were filled and analyzed online using google questioner tool. A questionnaire was personally administered to the student in the university. This method is chosen because the designed questionnaire could be collected within a short period of time and any doubts that the respondents might have rapidly could be clarified easily on the spot.

\subsection{Questionnaire Design}

The questionnaire contains Part I that was used to collect the demographic date. Part II have questions that intend to measure the students have awareness about e-learning, self-learning and distance learning, other question paragraphs measure the influencing factors as describe below: The awareness of students towards the use of elements of e-learning in the educational process. The respondents' evaluation of the effectiveness of using the elearning in the educational process. Difficulties experienced by students in the use of e- learning. Number of disciplines studied using e- learning. The amount of time students spent working in the e- learning environment. Activities / tasks that students performed directly in the e- learning environment. Students' opinion about the use of e-courses in the learning process. and the respondents' evaluation of the effect of using the e-leaning toward self study and self motivation

\subsection{Data Analysis Method}

After collected the data from the respondents, SPSS v.11.5 was used for data analysis statically, reliability analysis and regression analysis were applied in statistical analysis. Cronbach alpha measure was used to test the reliability of the questionnaire. A value with more than 0.7 means a good consistency. The value of Cronbach's alpha for all paragraphs are higher than 0.7 which indicate an acceptable values of research testing, the reliability in the $70 \%$ range was acceptable and those who were over $80 \%$ were good (Sekaran, 2003).

\section{Results}

\subsection{Analysis of Results}

Descriptive statistics was used which describe a series of observations in a data set parsimoniously, and in a meaningful way, which would enable individuals to get a feel for the basic characteristics of the data. Frequencies, mean, standard deviation and simple linear regression test are the most common descriptive used in data analysis for model building.

The questioner First part: The University role in educational citizenship

\begin{tabular}{lll}
\hline Paragraphs & Yes & No \\
\hline 1. The issues related to citizenship are highlighted through their plans and strategies. & $94.7 \%$ \\
2. Students are encouraged to maintain private and public property. & $92.4 \%$ \\
3 - Motivate students to consolidate the relationship between freedom and responsibility in & $93.9 \%$ \\
order to identify the rights and duties & $87 \%$ \\
4- Demonstrate the culture of quality and efficiency of work as a basis for belonging & $8 \%$ \\
5. Encourages the need for informed compliance with the University's goals as a way of & $86.9 \%$ \\
building the future & $80 \%$ & \\
$\begin{array}{l}\text { 6. Encourage students to need academic achievement as a basis for excellence. } \\
\text { 7- accuses the issues of scientific development as one of the issues of the renaissance of }\end{array}$ & $87.7 \%$ & 12. \\
society. & $86.2 \%$ & 13. \\
8- Diversity in ways of communication with students based on dialogue and discussion. & & 8 \\
& & 10. \\
9- Highlight the national dimension through the participation of students celebrations of the & $89.8 \%$ & 10. \\
university and its national and Islamic activities & & 2 \\
10 - Training students to adopt the scientific method in the discussion of issues and issues of & $89.9 \%$ & 10. \\
society & $87.7 \%$ & 12. \\
11. Provide activities and initiatives to develop the national spirit among students & & 3 \\
12- Special courses for students' programs that promote cultural identity and national & $81.7 \%$ & 18. \\
belonging & & 3 \\
\hline
\end{tabular}




\begin{tabular}{|c|c|c|}
\hline $\begin{array}{l}\text { 13. Intervene in resolving disputes within the university to maintain its organizational } \\
\text { structure. }\end{array}$ & $77.7 \%$ & 22. \\
\hline $\begin{array}{l}\text { 14. Support students to form committees of an educational nature, such as a reading } \\
\text { committee and follow-up committee }\end{array}$ & $84.6 \%$ & 15. \\
\hline $\begin{array}{l}\text { 15. Evaluations of the behaviors of the students translated into national identity are } \\
\text { continuously carried out. }\end{array}$ & $79.1 \%$ & $\begin{array}{l}20 . \\
9\end{array}$ \\
\hline $\begin{array}{l}\text { 16. Encourage students to adopt the principle of meaningful dialogue during their years of } \\
\text { study within their walls }\end{array}$ & $86.3 \%$ & $\begin{array}{l}13 . \\
7\end{array}$ \\
\hline 17. Instruct students how to deal with modern techniques and methods of use & $85.3 \%$ & 14. \\
\hline $\begin{array}{l}\text { 18. The students were directed to the need to respect the University administration and its } \\
\text { administrative staff }\end{array}$ & $91.5 \%$ & 8.5 \\
\hline $\begin{array}{l}19 \text { - Accused of building students' personalities in the interest of the institution first and then } \\
\text { the homeland II. }\end{array}$ & $81.5 \%$ & \\
\hline $\begin{array}{l}20 \text { - Accused of building the students' academic and professional building, in the interest of } \\
\text { serving the homeland and belonging to it. }\end{array}$ & $89.2 \%$ & $\begin{array}{l}10 . \\
8\end{array}$ \\
\hline
\end{tabular}

As we can see from table that the percentage of The issues related to citizenship are highlighted through their plans and strategies is $94.7 \%$. While the percentage of Students are encouraged to maintain private and public property 92.4\%. however the Motivate students to consolidate the relationship between freedom and responsibility in order to identify the rights and duties is $93.9 \%$ and the Demonstrate the culture of quality and efficiency of work as a basis for belonging percentage is $87 \%$. Furthermore the students answers was about if the university Encourages the need for informed compliance with the University's goals as a way of building the future is $86.9 \%$ and about if the university Encourage students to need academic achievement as a basis for excellence was $80 \%$. However the sample answer about that the university accuses the issues of scientific development as one of the issues of the renaissance of society $87.7 \%$. And it Diversity in ways of communication with students based on dialogue and discussion with $86.2 \%$ percentage.

The sample answers that the university highlight the national dimension through the participation of students celebrations of the university and its national and Islamic activities $89.8 \%$. And the university Training students to adopt the scientific method in the discussion of issues and issues of society $89.9 \%$. And it Provide activities and initiatives to develop the national spirit among students with percentage of $87.7 \%$. and the Special courses for students' programs that promote cultural identity and national belonging with percentage of $81.7 \%$. however, the sample answers if the university Intervene in resolving disputes within the university to maintain its organizational structure with percentage of $77.7 \%$. and that it Support students to form committees of an educational nature, such as a reading committee and follow-up committee with percentage of $84.6 \%$. And it Evaluations of the behaviors of the students translated into national identity are continuously carried out with percentage of $79.1 \%$. furthermore, the sample answers about that the university Encourage students to adopt the principle of meaningful dialogue during their years of study within their walls with percentage of $86.3 \%$. and they answer that the university Instruct students how to deal with modern techniques and methods of use with percentage of $85.3 \%$, and the answer that The students were directed to the need to respect the University administration and its administrative staff91.5\%. and the university Accused of building students' personalities in the interest of the institution first and then the homeland with percentage of $81.5 \%$. and they answered about that the university Accused of building the students' academic and professional building, in the interest of serving the homeland and belonging to it with percentage of $89.2 \%$.

\section{The questioner second part: The University role in political citizenship}

\begin{tabular}{lll}
\hline Paragraphs & Yes & No \\
\hline 1- the university adopt the method of dialogue in the issues related to the fate of the homeland. & 85.3 & 14.7 \\
2. In its policies, the national dimension is reflected in maintaining the unity of the Jordanian & 87.7 & 12.3 \\
national class. & & \\
3. Encourages students to seek all legitimate ways of defending the territory of their Jordanian & 88.5 & 11.5 \\
homeland. & & \\
4 - Refuses to resort to force in resolving disputes at the level of disagreement between students. & 84.8 & 15.2 \\
5 - enhance the sense of pride and honor of students because they are Jordanians. & 90.8 & 9.2 \\
\hline
\end{tabular}


6. Emphasizes the importance of political reconciliation in the face of external threats.

\begin{tabular}{ll}
86.4 & 13.6 \\
84 & 16 \\
89.2 & 10.8 \\
87.1 & 12.9 \\
& \\
90.8 & 9.2 \\
82.9 & 17.1 \\
87.6 & 12.4 \\
& \\
91.6 & 8.4 \\
79.5 & 20.5 \\
& \\
78.8 & 21.2 \\
87.8 & 12.2 \\
75.4 & 24.6 \\
& \\
72.7 & 27.3 \\
86.9 & 13.1 \\
87 & 13 \\
\hline
\end{tabular}

7. Discriminating between students on the basis of social class (citizen / refugee)

8. Emphasizes the need to exercise the freedom of the students and their facilities.

9. The history, achievements and sacrifices of the homeland and its struggles are presented from time to time

10. Instructs students to raise awareness of their rights and duties towards the country

11 - Students know the role of different national institutions in the service of society.

12 - warn students of the violation of national identity through the impact of negative techniques prevailing in society.

13. Encourages students to participate in various national events.

14. Encourages students to familiarize themselves with the articles of Jordanian law and constitution.

15. Encourages students to follow up political processes on the internal and regional levels.

16. Students have the principle of citizenship as a product of democracy

17. Students are encouraged that the individual's duties and responsibilities towards the country in return for political affiliation or partisan interest.

18. Talking about politics is a threat to it as an educational institution.

19. Show students the true picture of the relationship between the people and the authority.

The results in the table shows that $85.3 \%$ of the participants agree that the university adopt the method of dialogue in the issues related to the fate of the homeland, a percentage of 87.7agree that In its policies, the national dimension is reflected in maintaining the unity of the Jordanian national class, a percentage of 88.5 see that the university Encourages students to seek all legitimate ways of defending the territory of their Jordanian homeland and a percentage of 84.8 see that the university Refuses to resort to force in resolving disputes at the level of disagreement between students. However regarding if the university enhance the sense of pride and honor of students because they are Jordanians the answer was 90.8 percentage and if it Emphasizes the importance of political reconciliation in the face of external threats was 86.4 percentage and if it Discriminating between students on the basis of social class (citizen / refugee) the answer was $84 \%$. further the results shows that 89.2 agree that the university Emphasizes the need to exercise the freedom of the students and their facilities and the history, achievements and sacrifices of the homeland and its struggles are presented from time to time is 87.1.

the results shows that 90.8 agree that the university Instructs students to raise awareness of their rights and duties towards the country and 82.9 agree that Students know the role of different national institutions in the service of society. While the participants answer that if the university warn students of the violation of national identity through the impact of negative techniques prevailing in society with percentage of 87.6. and if it Encourages students to participate in various national events with percentage of 91.6 and 79.5 for the paragraph of Encourages students to familiarize themselves with the articles of Jordanian law and constitution. The results also showed that the university Encourages students to follow up political processes on the internal and regional levels with percentage of 78.8 .

the participants agree that students have the principle of citizenship as a product of democracy with percentage of 87.8 and Students are encouraged that the individual's duties and responsibilities towards the country in return for political affiliation or partisan interest with percentage of 75.4. some of the students see that Talking about politics is a threat to it as an educational institution with percentage of 72.7 . further, the sample agree with percentage of 86.9 that the university Show students the true picture of the relationship between the people and the authority. And they agree that Students believe that justice is the basis of government with percentage of 87 .

\section{The questioner Third part: The University role in social citizenship}

\begin{tabular}{lll}
\hline Paragraphs & yes & no \\
\hline 1. Citizenship is what makes national achievement a spirit in the formation of social sense & 93.1 & 6.9 \\
among students. & 91.6 & 8.4 \\
2. Urge students to understand the nature of the society in which they live & 92.3 & 7.7 \\
3. Emphasizes the need to build fraternal relations among students based on mutual respect & 91.6 & 8.4 \\
4 - Students are directed to the need to interact with various community institutions. & 90.7 & 9.3 \\
5 - works to instill good values and social customs of students. &
\end{tabular}


6 - Students return to respect the system and abide by regulations and restrictions.

88.5

89.2

87.8

8. Encourage students to be connected, friendly and friendly between students and the university administration.

9. Encourages students to work in the group and volunteer within the university facilities.

92.3

$86.6 \quad 13.4$

The results shows that the participants agree that citizenship is what makes national achievement a spirit in the formation of social sense among students with percentage of 93.1. and that the university Urge students to understand the nature of the society in which they live with percentage of $\mathbf{9 1 . 6}$ and it Emphasizes the need to build fraternal relations among students based on mutual respect with percentage of 92.3. however they see that Students are directed to the need to interact with various community institutions with percentage of 91.6. and they agree that the university works to instill good values and social customs of students with percentage of 90.7 . while 88.5 agree that Students return to respect the system and abide by regulations and restriction and 89.2 for positive attitudes of students towards the love and appreciation of work. However most of the sample see that the university Encourage students to be connected, friendly and friendly between students and the university administration with percentage of 87.8. it Encourages students to work in the group and volunteer within the university facilities with percentage of $\mathbf{9 2 . 3}$ and the university Denial of class discrimination on a social basis (eg sex)with percentage of 86.6

\section{The questioner Four part: The University role in economic citizenship}

\begin{tabular}{lll}
\hline Paragraphs & yes & no \\
\hline 1. Encourages students to preserve and protect the environment from various sources of pollution & 90.1 & 9.9 \\
as an indicator of good citizenship. & 85.5 & 14. \\
2- The economic risk resulting from non-preservation of public facilities at the university. & 5 \\
& 66.2 & 33. \\
3 - Students show that the increase in monthly income is the best indicator of the existence of & 8 \\
good citizenship or not. & 76.3 & 23. \\
4. Encourages students to rationalize consumption (water, electricity, communication) & 7 \\
$\begin{array}{l}\text { 5. The students should be obliged to pay dues for government services (water, electricity and } \\
\text { taxes) as a national duty. }\end{array}$ & 79.4 & 20. \\
6 - Encourages students and their families and community institutions to collect donations as a & 87 \\
kind of social and economic interdependence & 13 \\
7 - believes in the need for financial participation in the activation of various committees within & 83.1 & 16. \\
the university. & 9 \\
8. Encourages students to participate in fundraising and pay it to their beneficiaries. & 85.4 & 14. \\
9. Increase students' awareness of the need for scientific excellence as a basis for economic & 89.2 & 6. \\
growth in the knowledge society & 10. \\
10 - train students on the need to possess degrading skills, which in turn raise the economic level & 90.8 \\
and raise productivity. & 9.2
\end{tabular}

The results from the table shows that the university Encourages students to preserve and protect the environment from various sources of pollution as an indicator of good citizenship with percentage of 90.1. and most of them agree that The economic risk resulting from non-preservation of public facilities at the university with percentage of 85.5 however only 66.2 see that Students show that the increase in monthly income is the best indicator of the existence of good citizenship or not. and a percentage of 76.3 see that it Encourages students to rationalize consumption (water, electricity, communication). However a percentage of 79.4 see that The students should be obliged to pay dues for government services (water, electricity and taxes) as a national duty. How ever the sample agrre that the university Encourages students and their families and community institutions to collect donations as a kind of social and economic interdependence with percentage of 87 and they -believes in the need for financial participation in the activation of various committees within the university with percentage of 83.1 and it Encourages students to participate in fundraising and pay it to their beneficiaries with percentage of 85.4 . 
moreover the sample see that the university Increase students' awareness of the need for scientific excellence as a basis for economic growth in the knowledge society with percentage of 89.2 and it train students on the need to possess degrading skills, which in turn raise the economic level and raise productivity with percentage of 90.8

\section{Discussion and Recommendations}

From the tables above we can see that the university plays a major role in establishing good citizenship between students and the university have taken many steps to encourage the citizenship. For the political, economical, social points that we have discussed in the questioner we can see that the university The University role in political citizenship of students are:

- Defend the homeland and give ideas

- $\quad$ Teaching the role in the classroom

- $\quad$ Conducting educational seminars and hosting those who are in it

- $\quad$ Respect for all political parties

- $\quad$ Their role is to familiarize them with the importance of citizenship and the state and the people

- Perseverance for the homeland

- Highlighting the history and achievements of the nation

- Highlighting the history and achievements of the homeland such as highlighting the history of the day of dignity

- It cares about preserving and preserving the patriotism of the homeland

- effective role

- Work some activities that show solidarity with brotherly countries

- justice

- $\quad$ Pride in the homeland because we were Jordanians

- Use the dialog style

- Using the method of dialogue and discussion and preserving the soil of the homeland

- Enhances students' political citizenship

- Helping to belong to the homeland

- I do not know

- I do not think the university has a political role

- It has no role

- Hold seminars to hear student inquiries

- Loyalty

- It works to activate this citizenship and highlight it.

- Participation in political parties

- Helps to build a flexible political personality that accepts the other opinion and mutual dialogue

- Raising awareness of the student in the process of making the right decisions that relate to the fate of the homeland

- Helps select deputies

- Has an active role in achieving political citizenship

- To express my opinion freely, taking into consideration respect during expression and dialogue

- $\quad$ Promote political citizenship

- Hold seminars

- Encouraging political parties to build and reform society

The University role in social citizenship 
- $\quad$ The collective interest in which he lives and building relationships with students is a list of respect and respect

- $\quad$ Supports social citizenship

- Interaction between the people

- Teaching the student and mixing materials with the community

- All students have the opportunity to provide opportunities and activities

- Students have social communication

- Commitment of the individual to the laws and away from corruption and the establishment of justice and equality among individuals

- Encourages students to volunteer and group work within the university, such as volunteering to harvest olives

- Students' communication and communication skills are stimulated

- Emphasize the brothers among the students

- Development of interpersonal relations

- Have a positive role in trying to stitch some values, including cooperation

- $\quad$ Raise the social level

- Understand the nature of society in which they live and respect the system

- Pride and honor we are Jordanians

- Confirm the spirit of the brothers among the students

- Strengthen their social attitudes in the students on the ground

- Helps to cooperate and social solidarity

- We got to know the community we live in and build relationships with colleagues

- Encourage us to recognize and interact with different people

- Develop capacity for self-interest and interaction with society

- Hold seminars for students

- Cooperation between university members in social activities

- Make the individual a social object open to others and have an active role in society and adapted in the environment

- Helps to deal with others and respect them

- It has many positive roles in citizenship, especially in social terms

- Express the student's opinion with transparency

- Always look for achievement and creativity and be an active person in society

- Promote social citizenship

- Hold sessions

- Promote social cohesion, cooperation and adaptation

The University role in economic citizenship

- Supports economic citizenship

- Maintenance of public and private facilities

- Teaching the Student Account

- Provide financial facilities for students such as discounts

- Interested in the view of the university through the trees and the preservation of it

- To instill in individuals the love of work, volunteerism and initiatives

- Students are instructed to pay government services (water and electricity) to provide for the student 
- Encourages the conservation of trees and the consumption of water

- Encourages students to preserve and protect the environment from various sources of pollution as an indicator of good citizenship

- Grants and loans

- $\quad$ Raise the economic level

- Encourage reduced costs

- Reducing water and electricity consumption

- Guidance on water and electricity consumption

- It promotes awareness of economic citizenship

- Helping to volunteer collectively

- Encourage us to Takaful

- Increasing youth in need of jobs and developing the labor market

- Hold seminars for students

- Participation in active economic activities

- Helps individuals in how to act economically in all their aspects

- Helps the student how to save

- $\quad$ They are very interested in economic citizenship

- $\quad$ The social service is properly stimulated

- $\quad$ Through the preservation of the country and its economic assets of various tools and others

- $\quad$ Promote economic citizenship

- Hold sessions

- Supports, lifts and develops the economy

The ways in which the university activates students role in promoting the principles of good citizenship for its students are summarized as follows

- $\quad$ Participate in community service and do not graduate without work

- Participate in cultural activities to enhance the role of the university student in order to be active and raise awareness in the national culture of the Jordanian countries and cultural exchange among civilizations

- $\quad$ Activities held at the university

- $\quad$ There is a national education course that encourages the need for good citizenship and some community service activities such as tree planting.

- $\quad$ Through community points that are the requirement of graduation for each student such as celebrations and volunteer work

- $\quad$ Through elections and groups that talk about demand

- $\quad$ Participation in the activities held by the university and the ability to express the private opinion

- Compliance with laws and regulations

- It works to increase awareness among students and increase their effectiveness in the community by participating in various student activities

- $\quad$ Through discussion, dialogue and communication with them

- One way to do this is to have transportation to every college and to take care of activities that are fun for the individual

- $\quad$ Through activities and volunteer work

- Through the university's activities and awareness activities that are advertised on the university's website and student activities 
- $\quad$ The establishment of seminars and initiatives through which students are given the opportunity to talk about many things that serve the person and the community

- $\quad$ Through courses and seminars held in them and through various activities

- Allow the student to hold peaceful demonstrations and allow them to freely express their opinion

- The University of Jordan offered seminars, lectures and discussions between students and doctors to express their views and suggestions for development and change

- Ways are that they use justice and equality

- Through seminars and targeted activities

- $\quad$ To make us a role in making decisions that are in the interest of the student

- $\quad$ Through participation in humanitarian activities and community service

- $\quad$ Through participation in community services

- Citizenship is not based on the individual's enjoyment of his or her rights in a society but it means community partnership in the national project for development and development.

- Awareness through activities and through the curriculum

- Use and activation of discussions in colleges

- $\quad$ Student Council and community service seminars and conferences

- Action initiatives

- Seminars

- Meetings

- Democracy and opinion

- Democracy and freedom of opinion

- Volunteerism ... lectures ... awareness through seminars ... in many doctors indicate a good citizen example for students

- Community Service ... Council of Students Union .. Conferences and seminars held by the University

- Encourages the student to hold seminars on anything related to the country and also encourages the demand for charitable work as student activities both inside and outside the university.

- Keeping the environment clean, complying with laws, preserving private and public property, reducing expenses for unimportant things, respecting others, not forcing others to buy that they do not want

- $\quad$ Activities, means and national institutions

- Activities and means Role of national institutions

- $\quad$ Through community participation and targeted community service

- Lecture lectures on activating the role of the student.

- Conducting awareness lectures for students on the extent of his influence as a citizen of his country and establishing and correcting his principles

- Develop the role of the student in citizenship in various ways and ways, such as stitching values and societal norms, respecting the country and citizens, respecting laws and regulations, promoting dialogue among students, respecting the freedom of opinions and differences, and emphasizing the cleanliness of the environment and public property. Racism among students.

- $\quad$ Through awareness and activities

- $\quad$ Through the course of ethics of university life and through seminars and lectures that strengthen our role in good citizenship

- $\quad$ The University shall form and strengthen the character of the student to defend his rights and be a good citizen

- Events, activities and external seminars

- $\quad$ Participate in university interactions 
- Open the door to dialogue and discussion

- Through the awareness lectures and the activities that the university holds

- And increase awareness on demand through programs and conferences

- By inculcating students' values and attitudes through discussion

- Seminars and lectures

- Through the activities carried out by the character and the demand union

- Through the work of seminars and workshops that enhance the spirit of citizenship within us

- Charitable initiatives, seminars and lectures held at the University

- The community service that it imposed on the university students to participate in addition to the celebrations and events

- By opening the way for participation in activities and initiatives that enhance my role as an active member of society and accomplished in his community

- Preserving university property and our sense of being an effective member

- Conducting meetings, seminars and celebrations

- the establishment of initiatives and workshops that stimulate the principles of citizenship to the student

- have a system of community service that allows the student to know how to practice citizenship in all areas

- Holding seminars on community culture participating in important seminars and workshops for the development of cultural awareness

- Take my students 'opinions and consult them and work for the Student Union so that they know the students' requirements and have freedom of expression

- Holding workshops in the university

- Hold sessions

\section{References}

Bennett, W. L., Bers, M., Coleman, S., Earl, J., Foot, K., Levine, P., Montgomery, K., Raynes-Goldie, K., Rheingold, H., Schussman, A., Walker, L., \& Xenos, M. (2006). 'MacArthur online discussions on civic engagement: September 29-October 13 2006'. Online. Retrieved 16 October 2011, from http://spotlight.macfound.org/resources/Civic_EngagementOnline_Discussions'06.pdf

Bennett, W. L., Wells, C., \& Rank, A. (2009). Young citizens and civic learning: Two paradigms of citizenship in the digital age. Citizenship Studies, 13(2), 105-20.

Burlen, K. (2003). On the relationship between citizenship and society. Citizen Citizen. Political citizenship and social citizenship, Paris, L'Harmattan, al. Social Logic.

Carnegie Corporation of New York \& CIRCLE (2003). The civic mission of schools. New York: Carnegie Corporation.

Chauvière, M., \& Godbout, J. T. (eds). (1992). Users between market and citizenship, Paris, The Harmattan.

Colas, D., Emery, C., \& Zylberberg, J. (1991). His defining relations with "the other concept". Citizenship and Nationality, Paris, PUF, coll. Today's Politics.

Constant, F. (1998). A recent synthesis. Citizenship, Paris, Montchrestien, coll. Clefs.

Crick, B. (2007). Citizenship: The political and the democratic. British Journal of Educational Studies, 55(3), 235248.

Crick, B., \& Porter, A. (Eds.) (1978). Political education and political literacy. London: Longman

Farouk, A. F. A., \& Husin, A. (2011). Civic education in an emerging democracy: Students' experiences in Malaysia’s Projek Warga. Asian Social Science, 7(3), 154-165.

Harkavy, I. (2006). The role of universities in advancing citizenship and social justice in the 21 st century. Education, Citizenship and Social Justice, 1(1), 5-37.

Ke, L., \& Starkey, H. (2014). Active citizens, good citizens, and insouciant bystanders: The educational 
implications of Chinese university students' civic participation via social networking. London Review of Education, 12(1), 50-62.

Koubi, G. (1995). An interdisciplinary vision. Of citizenship, Paris, Litec.

Kymlicka, W. (1997). Education for citizenship. 1997 Institut für Höhere Studien. Institute for Advanced Studies (IHS) Josefstädter Straße, 39, A-1080 Wien.

Livingstone, S., Bober, M., \& Helsper, E. (2005). Active participation or just more information? Young people's take-up of opportunities to act and interact on the internet. Information, Communication and Society, 8(3), 287-314.

Magnette, P. (2001). The story of the concept. Citizenship, a history of the idea of participation, Brussels, Bruylant.

Matsuda, N. (2014). Can Universities Supply Citizenship Education.

Molina Girón, L. A. (2012). Educating good citizens: A case study of citizenship education in four multicultural high school classrooms in Ontario (Doctoral dissertation, Université d'Ottawa/University of Ottawa.

Monicah, Z. (2018). Democratic citizenship education in Zimbabwe's higher education system and its implications for teaching and learning (Doctoral dissertation, Stellenbosch: Stellenbosch University).

Newmann, F. M. (1975). Education for citizenship action: Challenge for secondary curriculum. Berkeley, CA: MrCutchan Publishing Corporation.

Parker, W. (2003). Teaching democracy: Unity and diversity in public life. New York: Teachers College.

Xiao, P., \& Tong, H. (2010). Aims and methods of civic education in today's universities of China. Asian Social Science, 6(4), 44-49.

\section{Copyrights}

Copyright for this article is retained by the author(s), with first publication rights granted to the journal.

This is an open-access article distributed under the terms and conditions of the Creative Commons Attribution license (http://creativecommons.org/licenses/by/4.0/). 